\title{
Microstructure Analysis and Mechanical Properties of Low Alloyed Steel with Retained Aus- tenite Obtained by Heat Treatment
}

Ludmila Kučerová, Andrea Jandová, Kateřina Rubešová

Regional Technological Institute, University of West Bohemia in Pilsen, Univerzitní 8, 30614 Plzeň. Czech Republic. Email: skal@rti.zcu.cu, jandovaa@rti.zcu.cz,krubesov@rti.zcu.cz

Four different heating temperatures in the range of $770{ }^{\circ} \mathrm{C}-950{ }^{\circ} \mathrm{C}$ were used for laboratory heat treatment of low carbon low alloyed steel. Chemical composition of the steel was based on the most common TRIP steel concept, only the silicon content was lowered to $0.6 \%$ and it was partially replaced by $1.4 \%$ of aluminium. The steel was further micro-alloyed by niobium. Two different ways of cooling were applied to the samples. The first set was cooled to $425^{\circ} \mathrm{C}$ in a salt bath with the temperature of $200{ }^{\circ} \mathrm{C}$, the second set was cooled to $425{ }^{\circ} \mathrm{C}$ in a salt bath heated to the temperature of $400{ }^{\circ} \mathrm{C}$. In this way, two distinctive cooling rates were achieved for every soaking temperature. Once the samples reached $4250^{\circ} \mathrm{C}$, they were in all cases removed to the furnace for 20 minute hold at the temperature of $425^{\circ} \mathrm{C}$. The final cooling was carried out in air. Resulting microstructures were analysed by scanning electron microscopy and consisted of various amounts of ferrite, bainite and retained austenite. Tensile strength in the range of $750-908 \mathrm{MPa}$ was obtained with total elongation of $33-42 \%$.

Keywords: TRIP steel, Aluminium, Heat treatment, Retained austenite

\section{Introduction}

TRIP (transformation induced plasticity) steels are high strength low alloyed steels that can be produced either by heat or thermo-mechanical treatment [1-3]. Heat treatment typically consists of two step annealing with the second hold in the temperature region of bainitic transformation [4-6]. The aim of the processing is to prepare multiphase microstructure containing ferrite, carbide-free bainite and retained austenite [7-10]. This microstructure has the potential to utilize TRIP effect, when metastable retained austenite transforms to martensite during plastic deformation. When gradual transformation occurs during straining, the offset of necking is postponed and uniform plastic deformation of the steel is enhanced and ultimate tensile strength is increased at the same time. The presence of hard martensitic islands and thin films in the microstructure results in further increase of the strength of the steel. Due to this effect, TRIP steels can be used to decrease the weight of formed parts in automotive industry.

First generation of TRIP steels was based on $0.2-0.4 \%$ C- $1-2 \% \mathrm{Mn}-1-2 \% \mathrm{Si}$ alloying concept, which ensured stabilization of around $10-15 \%$ of retained austenite and interesting combinations of tensile strength and ductility $[1,11]$. Manganese was used to support retained austenite stabilization and silicon was added mainly to suppress carbide precipitation during the hold in bainite transformation temperature region. Retention of austenite is achieved by combined effects of geometrical and chemical stabilization and carbon content in retained austenite is therefore typically high (around $1-2 \%$ ) [1, 7$10]$. This is the reason why carbide formation is undesirable during the processing, as it consumes carbon needed for stabilization of retained austenite. Higher carbon content means higher stability of a particular island or lath of retained austenite, but does not necessarily result also in better mechanical properties. Particularly small islands and thin films of retained austenite tend to possess higher carbon contents and might be therefore over-stabilized. It means that they do not transform at all during straining and thus do not contribute to the enhancement of mechanical properties. Higher silicon contents used in TRIP steels presented problems with welding and galvanizing, which are both important for an automotive industry. Other alloying concepts have been investigated to improve the performance of the steel in these two areas without loss of mechanical properties [12-17]. One of the solutions seemed to be partial substitution of silicon by aluminium. Complete substitution was not successful, aluminium has similar effect on austenite stability and solid solution strengthening as silicon, however the effect is weaker and the steel possessed lower strength [7-9].

\section{Experimental Program}

Tab. 1 Chemical composition of experimental steel in weight $\%$

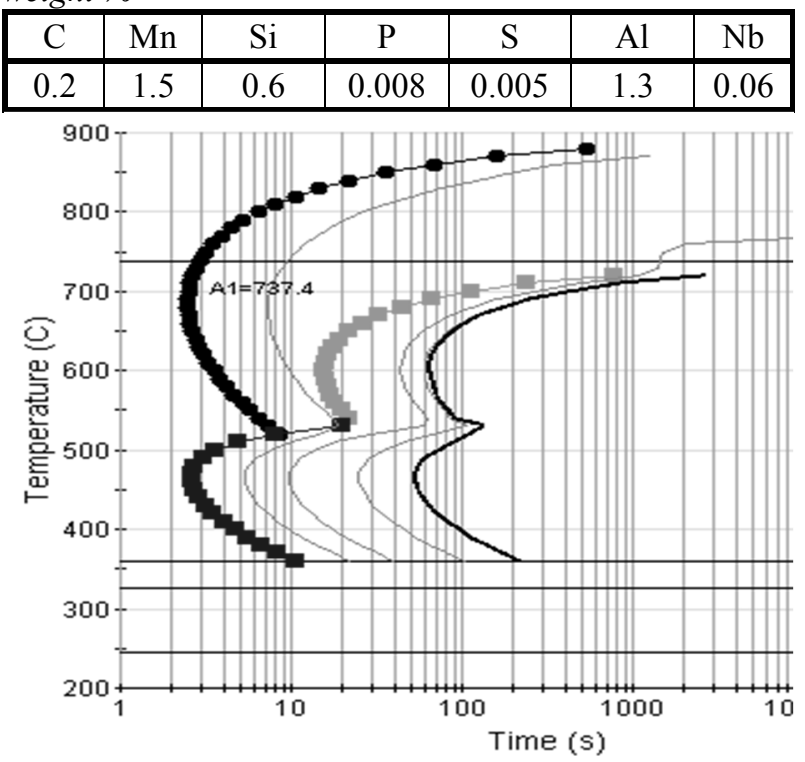

Fig. 1 TTT diagram of experimental steel calculated in JMatPro software 
Low alloyed experimental steel (Tab. 1) was prepared as a $250 \mathrm{~kg}$ ingot using a laboratory vacuum furnace. The ingot was divided into four parts and re-forged at the temperature of $1150{ }^{\circ} \mathrm{C}$. Forged bars were subsequently annealed for two hours at $950{ }^{\circ} \mathrm{C}$ and air cooled to room temperature.

Cylindrical samples with the length of $5 \mathrm{~cm}$ were cut directly from the bars and used for heat treatment in the laboratory furnace. Soaking temperatures of $770{ }^{\circ} \mathrm{C}, 800$ ${ }^{\circ} \mathrm{C}, 850{ }^{\circ} \mathrm{C}$ and $900{ }^{\circ} \mathrm{C}$ were applied to the steel and soaking hold was always 20 minutes. The samples were than cooled in salt bath heated to the temperature of either 200 ${ }^{\circ} \mathrm{C}$ or $400{ }^{\circ} \mathrm{C}$ to obtain two different cooling rates. Cooling rate of the samples cooled in salt bath with the temperature of $200{ }^{\circ} \mathrm{C}$ was around $27{ }^{\circ} \mathrm{C} / \mathrm{s}$, while samples cooled in $400{ }^{\circ} \mathrm{C}$ salt bath reached lower cooling rates around $13{ }^{\circ} \mathrm{C} / \mathrm{s}$. According to previous works carried out at the steel with similar chemical composition without aluminium [3, 13, 14] and TTT (time temperature transformation) diagram of experimentsaltal steel calculated in JMatPro (Fig. 1), even the lower cooling rate should be high enough to prevent pearlite formation during the cooling. The temperature of every sample was monitored during heat treatment by a set of thermocouples of MTC
11 type, inserted into holes drilled around $8 \mathrm{~mm}$ under the surface of the sample. Once the temperature of the sample dropped to $425^{\circ} \mathrm{C}$, the sample was always moved to laboratory furnace heated to $425{ }^{\circ} \mathrm{C}$ and hold there for another 20 minutes to allow formation of sufficient amount of bainite in the final microstructure. PK 130/12 a DKO 4 furnaces were used for heat treatment of the steel.

Metallographic cross sections were prepared from heat treated samples in transverse direction (perpendicular to the axes of the bars) and etched in 3\% Nital. The resulting microstructures were analysed using a Zeiss EVO 25 scanning electron microscope with a LaB6 cathode and an Olympus BX61 light microscope. The volume fraction of the retained austenite was determined by $\mathrm{X}$ ray diffraction phase analysis using an AXS Bruker D8 Discover automatic powder diffractometer with a HISTAR detector and Co lamp using integrated intensities of (200) ferrite peak and (111), (002) and (022) austenite peaks. Mechanical properties were evaluated by tensile test of flat dog-boned sub-sized samples with gauge length of $5 \mathrm{~mm}$ and the cross section of $2 \times 1.2 \mathrm{~mm}$. Carbon content in retained austenite was calculated considering the effect of alloying elements according to [13]:

$$
\mathrm{a}=3.572+0.0012 \mathrm{Mn}-0.00157 \mathrm{Si}+0.0056 \mathrm{Al}+0.033 \mathrm{C}
$$

Where: a... lattice parameter of the retained austenite calculated from the three austenite peaks measured by Xray diffraction phase analysis. The amounts of alloying elements are given in weight percent.

\section{Results and discussion}

\subsection{Samples cooled in salt bath with $200{ }^{\circ} \mathrm{C}$}

All three samples processed with cooling in salt bath with the temperature of $200{ }^{\circ} \mathrm{C}$ possessed bainite-based microstructures with $12-17 \%$ of retained austenite with yield strengths of 568-658 MPa, good tensile strengths in the region of $814-843 \mathrm{MPa}$ and high total elongation of $40-42 \%$ (Tab. 2). Carbon contents in the retained austenite were also high, reaching the values between $1.892 \%$ and $2.052 \%$, suggesting high chemical stabilization of the retained austenite.

Tab. 2 Mechanical properties, retained austenite volume fraction and carbon content in retained austenite

\begin{tabular}{|c|c|c|c|c|c|c|}
\hline Soaking temperature $\left[{ }^{\circ} \mathrm{C}\right]$ & Salt bath temperature $\left[{ }^{\circ} \mathrm{C}\right]$ & $\operatorname{Re}[\mathrm{MPa}]$ & $\mathrm{Rm}[\mathrm{MPa}]$ & $\mathrm{A}[\%]$ & $\mathrm{RA}[\%]$ & $\mathrm{C}$ in RA [\%] \\
\hline 850 & \multirow{3}{*}{200} & 568 & 830 & 42 & 15 & 1.895 \\
\hline 900 & & 591 & 814 & 40 & 17 & 1.892 \\
\hline 950 & & 658 & 843 & 40 & 12 & 2.052 \\
\hline 770 & \multirow{3}{*}{400} & 396 & 750 & 41 & 18 & 1.855 \\
\hline 850 & & 410 & 815 & 39 & 16 & 1.762 \\
\hline 900 & & 435 & 856 & 37 & 11 & 1.601 \\
\hline
\end{tabular}

Heat treatment with soaking temperature of $850{ }^{\circ} \mathrm{C}$ produced bainitic-ferritic microstructure with small amount of proeutectoid ferrite and $15 \%$ of retained austenite. Bainitic microstructure consisted of the mixture of lath and granular bainite, both of them being carbide-free. This microstructure reached the highest total elongation of $42 \%$ combined with relatively high tensile strength of $830 \mathrm{MPa}$.

Increasing soaking temperature from $850{ }^{\circ} \mathrm{C}$ to 900 ${ }^{\circ} \mathrm{C}$ decreased the amount of proeutectoid ferrite formed at prior austenite grain boundaries (Fig. 2 - Fig. 4). The resulting microstructure was predominantly bainitic with $17 \%$ of retained austenite. Carbon content in the retained austenite was the same as in the microstructure soaked at
$850{ }^{\circ} \mathrm{C}$. Larger areas of bainitic ferrite were observed in the microstructure, which obtained lower tensile strength of $814 \mathrm{MPa}$ and total elongation of $40 \%$.

Further increase of soaking temperature to $950{ }^{\circ} \mathrm{C}$ decreased even the thickness of bainitic ferrite laths (Fig. 2, Fig. 5). Lath morphology of the bainite was prevailing in this microstructure. The lowest volume fraction of retained austenite $(12 \%)$ was measured in the sample soaked at the highest temperature of $950{ }^{\circ} \mathrm{C}$ (Tab. 2), however it contained the highest amount of carbon above $2 \%$. This microstructure achieved higher yield and tensile strengths of $658 \mathrm{MPa}$ and $843 \mathrm{MPa}$ respectively, than the previous two samples processed at lower temperature. 

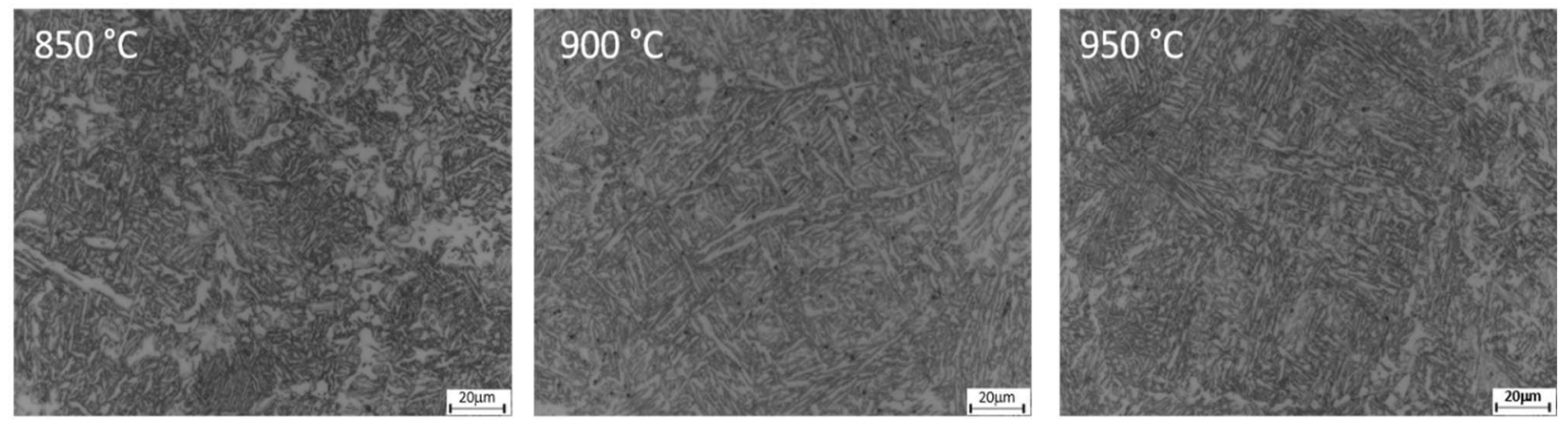

Fig. 2 Comparison of microstructures obtained by soaking at $850^{\circ} \mathrm{C}, 900^{\circ} \mathrm{C}, 950{ }^{\circ} \mathrm{C}$ and cooled in salt bath with the temperature of $200^{\circ} \mathrm{C}$

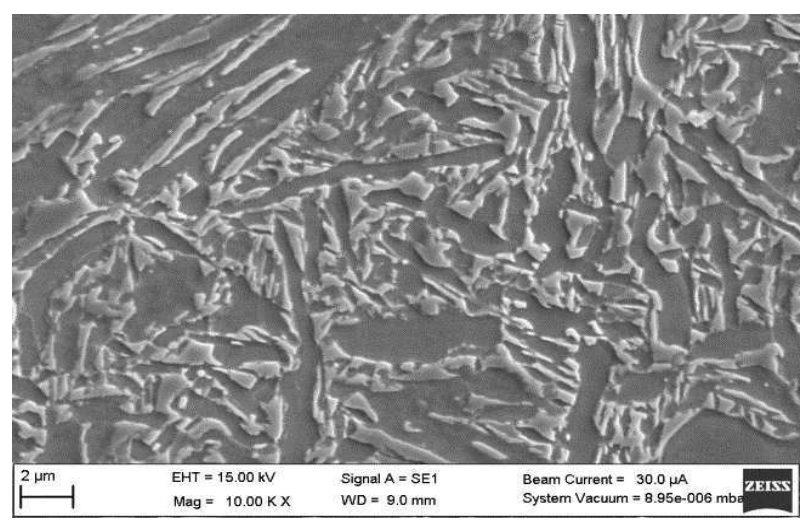

Fig. $3850{ }^{\circ} \mathrm{C}-200^{\circ} \mathrm{C}$ salt bath, mixture of lath and granular bainite

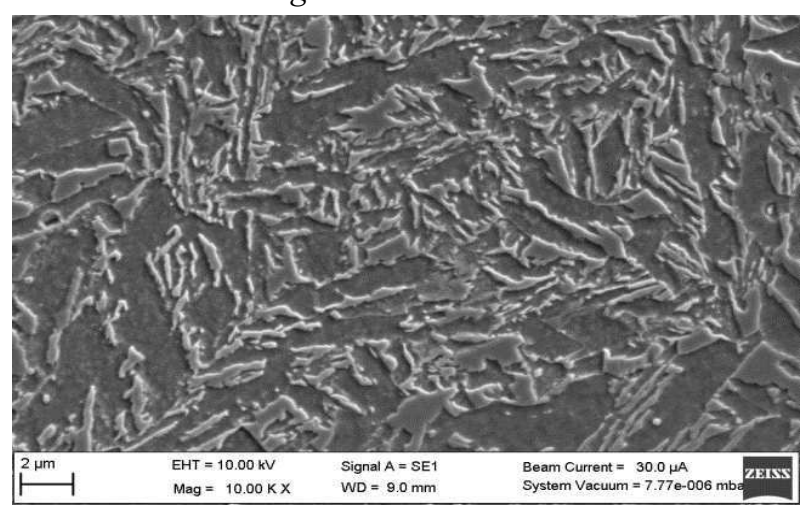

Fig. $4900{ }^{\circ} \mathrm{C}-200{ }^{\circ} \mathrm{C}$ salt bath, bainite with occasionally broader areas of bainitic ferrite

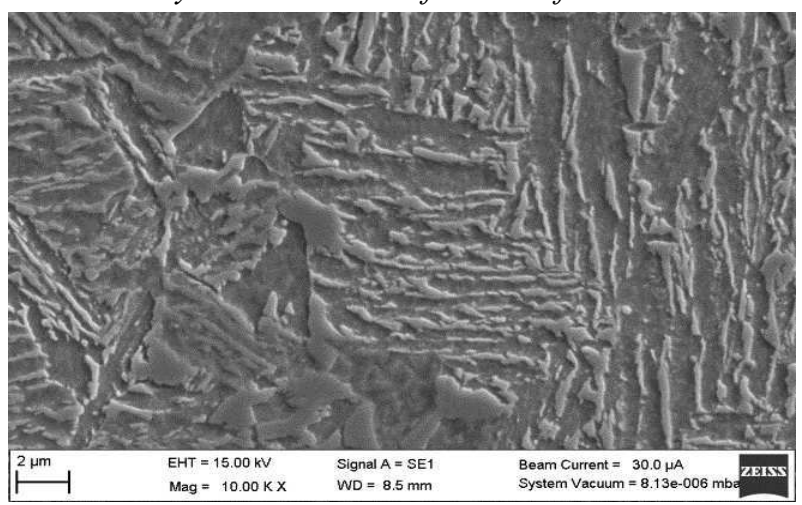

Fig. $5950{ }^{\circ} \mathrm{C}-200{ }^{\circ} \mathrm{C}$ salt bath, lath bainite with rather long laths

\subsection{Samples cooled in salt bath with $400{ }^{\circ} \mathrm{C}$}

The lowest soaking temperature of $770{ }^{\circ} \mathrm{C}$ was in the intercritical ferrite-austenite region, as can be seen from the comparison of light micrographs of this sample with the one soaked at $850^{\circ} \mathrm{C}$ (Fig. 6 - Fig. 8). There are large grains of original polygonal ferrite in the sample soaked at $770{ }^{\circ} \mathrm{C}$, which did not transform to austenite during soaking. SEM details from a bainitic region show the mixture of granular and lath bainite (Fig. 7). There are also small bulky islands of retained austenite or M-A constituent, particularly at the edges of bainitic areas. Larger amount of polygonal ferrite in the final microstructure was responsible for the drop of yield and ultimate tensile strengths to $396 \mathrm{MPa}$ and $750 \mathrm{MPa}$, respectively. Due to the small carbon solubility in ferrite, more carbon remained for retained austenite stabilization, increasing its volume fraction to $18 \%$. Carbon content in retained austenite was also relatively high, reaching $1.855 \%$.

There was practically no polygonal ferrite in the microstructure obtained by soaking at $850^{\circ} \mathrm{C}$ and slow cooling (Fig. 8). The microstructure was predominantly bainitic and consisted of the mixture of various bainitic morphologies, ranging from larger packets of lath bainite to granular bainite and $16 \%$ of retained austenite. An average combination of tensile strength of $815 \mathrm{MPa}$ and $39 \%$ total elongation was obtained for this microstructure. Carbon content in retained austenite decreased significantly to $1.762 \%$ in comparison to the previous treatment with lower soaking temperature.

The soaking temperature of $900{ }^{\circ} \mathrm{C}$ combined with lower cooling rate resulted in the formation of large islands of M-A constituent with complex shapes and distinctive areas with martensitic laths (Fig. 6, Fig. 9). The amount of retained austenite found in this microstructure was only $11 \%$, which was the lowest value obtained in this work. In combination with the lowest carbon content of $1.6 \%$, it suggest the lowest stability of retained austenite in this sample. High amount of martensite would contribute to the highest strength and lowest total elongation of the sample. There are some fine grains of proeutectoid ferrite, which were not observed in the previous sample; however the amount of bainitic ferrite seems to be lower than in the case of sample soaked at $850{ }^{\circ} \mathrm{C}$. 

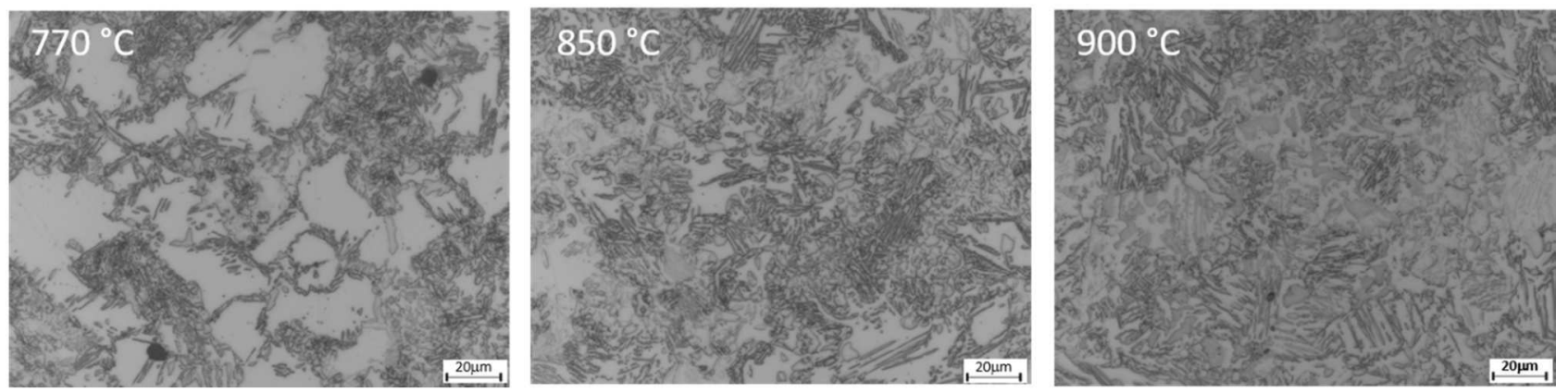

Fig. 6 Comparison of microstructures obtained by soaking at $770{ }^{\circ} \mathrm{C}, 850^{\circ} \mathrm{C}, 900{ }^{\circ} \mathrm{C}$ and cooled in salt bath with the temperature of $400^{\circ} \mathrm{C}$

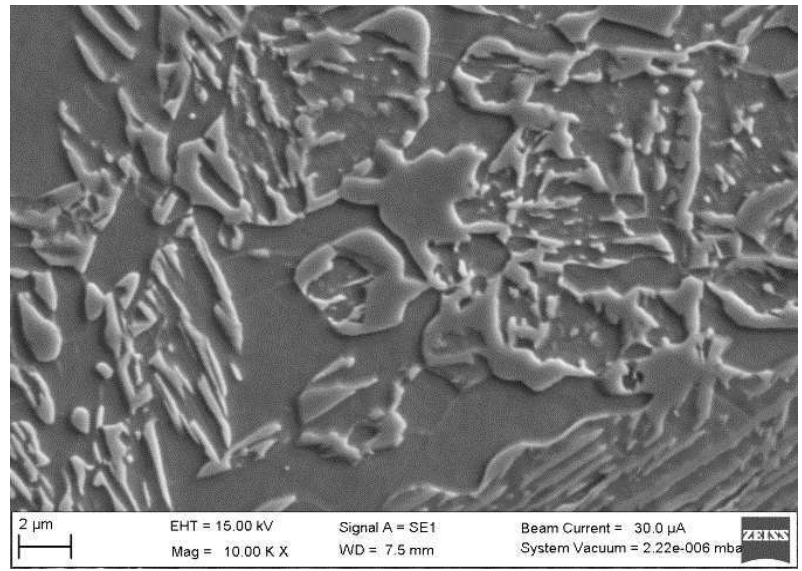

Fig. $7770^{\circ} \mathrm{C}-400^{\circ} \mathrm{C}$ salt bath, detail from bainitic area

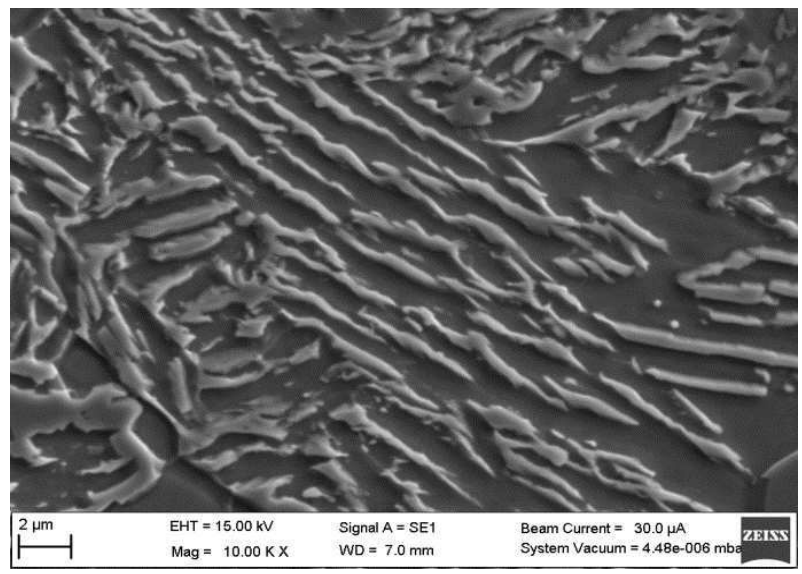

Fig. $8850{ }^{\circ} \mathrm{C}-400^{\circ} \mathrm{C}$ salt bath, lath bainite

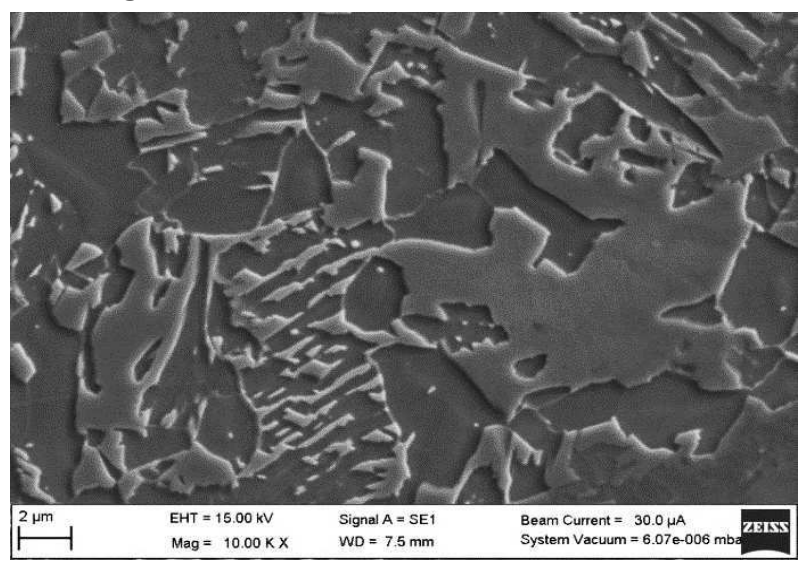

Fig. $9900{ }^{\circ} \mathrm{C}-400{ }^{\circ} \mathrm{C}$ salt bath, small area of lath bainite and large islands of $M-A$ constituent
Retained austenite volume fraction decreased with increasing soaking temperature for the samples cooled in salt bath heated to $400{ }^{\circ} \mathrm{C}$. The correlation of decreasing retained austenite volume fraction to decreasing its carbon content was observed. These results are in agreement with results obtained by Wang et al. [12] at $0.25 \mathrm{C}-1.23 \mathrm{Si}-$ $2.09 \mathrm{Mn}-2.92 \mathrm{Al}$ steel. On the other hand, no similar correlation between soaking temperature, retained austenite volume fraction and retained austenite carbon content was found in the samples cooled in salt bath heated to 200 ${ }^{\circ} \mathrm{C}$, where the highest carbon content above $2 \%$ was determined for the lowest volume fraction of retained austenite of $12 \%$.

\section{Conclusions}

The volume fraction of retained austenite was for all treatments between 11 and $18 \%$. With the exception of sample soaked at $770{ }^{\circ} \mathrm{C}$, tensile strengths of 815-850 $\mathrm{MPa}$ were obtained. Increasing temperature of soaking hold decreased the amount of proeutectoid ferrite at prior austenite grain boundaries. Bainite-based microstructures with retained austenite carbon contents were obtained by the treatments with cooling at $27^{\circ} \mathrm{C} / \mathrm{s}$ carried out in 200 ${ }^{\circ} \mathrm{C}$ salt bath. There was more ferrite and ferritic islands and laths were thicker and longer in the samples cooled at $13{ }^{\circ} \mathrm{C} / \mathrm{s}$ in $400{ }^{\circ} \mathrm{C}$ salt bath. The microstructures obtained by slower cooling were generally coarser, retained austenite laths were also longer, retained austenite carbon contents were lower and lath bainite morphology was more pronounced. Sample processed with soaking temperature of $900{ }^{\circ} \mathrm{C}$ and slower cooling had distinctively larger islands of M-A constituent.

For the samples cooled in the $400{ }^{\circ} \mathrm{C}$ salt bath, there was a distinctive trend in mechanical properties and retained austenite volume fraction, which was not seen in the first set of quicker cooled samples. Yield and ultimate tensile strengths both increased with increasing soaking temperature, while retained austenite volume fraction and total elongation decreased at the same time. Retained austenite carbon content decreased with decreasing retained austenite volume fraction.

\section{Acknowledgement}

The present contribution has been prepared within project LO1502 'Development of the Regional Technological Institute' under the auspices of the National Sustainability Programme I of the Ministry of Education, Youth and Sports of the Czech Republic. 


\section{References}

[1] TALAPATRA, A., BANDHYOPADHYAY, N. R., DATTA, J. (2013). Correlation between Heat Treatment, Microstructure and Properties of TripAssisted Steels. In: World Academy of Science, Engineering and Technology, International Journal of Mechanical, Aerospace, Industrial, Mechatronic and Manufacturing Engineering, Vol. 7, No. 4, pp. 80-85

[2] NEMECEK, S., NOVY, Z., STANKOVA, H. (2006). Optimization of heat treatment of TRIP steels. In: La metallurgia italiana, pp. 47-51.

[3] KUČEROVÁ, L., OPATOVÁ, K., KÁŇA, J., JIRKOVÁ, H. (2017). High Versatility of Niobium Alloyed AHSS, In: Arch. Metall. Mater., Vol. 62, No. 3, pp. 1485-1491.

[4] KUČEROVÁ, L., BYSTRIANSKÝ, M., JENÍČEK, Š., FRANCISCO, P. (2017). Effect of Deformation Conditions on Microstructure and Mechanical Properties of Low Alloyed Steel. In: Manufacturing Technology, Vol. 17, No 5, pp. 752-756.

[5] LI, S., ZHU, R., KARAMAN, I., ARRO'YAVE, R. (2012). Thermodynamic analysis of two-stage heat treatment in TRIP steels. In: Acta Materialia, Vol. 60, pp. 6120-6130. Elsevier Ltd.

[6] NEMECEK, S., NOVÝ, Z. (2006). Microstructure in TRIP steels after intercritical heat treatment, In: Proceedings of The 3rd International Conference on Advanced Structural Steels Gyeongju, Korea, August 22-24.

[7] DING, W., HEDSTORM, P., LI, Y. (2016). Heat treatment, microstructure and mechanical properties of a C-Mn-Al-P hot dip galvanizing TRIP steel. In: Materials Science \& Engineering, Vol. A 674, pp. 151-157. Elsevier Ltd.

[8] KUČEROVÁ, L., JIRKOVÁ, H., VOLKMANNOVÁ, J., VRTÁČEK, J. (2018). Effect of Aluminium and Manganese Contents on the Microstructure Development of Forged and Annealed TRIP Steel. In: Manufacturing Technology, Vol. 18, No. 4, pp. 605-610.

[9] SUH, D.W., PARK, S.J, OH, Ch.S., KI, S.J. (2007). Influence of partial replacement of Si by
$\mathrm{Al}$ on the change of phase fraction during heat treatment of TRIP steels, In: Scripta Materialia, Vol. 5, pp. 1097-1100. Elsevier Ltd.

[10] Xie, P. et al. (2017). A high-performance TRIP steel enhanced by ultrafine grains and hardening precipitates. In: Materials \& Design, Vol. 127, pp. 1-7.

[11] ZHANG, Z.G., GICHIMANABE, K. (2014). Influence of Heat Treatment on Hydro formability of TRIP Seamless Steel Tube, In: JOURNAL OF IRON AND STEEL RESEARCH, INTERNATIONAL, Vol. 21. No. 7, pp. 695 -701. Elsevier Ltd

[12] WANG , H.S. et al. (2017). Microstructure and mechanical properties of hot-rolled and heat-treated TRIP steel with direct quenching process, In: Materials Science and Engineering A,Vol. 702, pp. 350-359.

[13] KUČEROVÁ, L., JIRKOVÁ, H., MAŠEK, B. (2016). Influence of Nb Micro-alloying on TRIP Steels Treated by Continuous Cooling Process. In: Manufacturing Technology, Vol. 16, No. 1, pp. 145-149.

[14] JENÍČEK, Š., VOREL, I., KÁŇA, J. (2018). Metallographic Observation for Evaluating Microstructural Evolution on Various CrossSections of Forged Part upon Air Cooling from Finishing Temperature. In: Manufacturing Technology, Vol. 18, No. 1, pp. 53-56.

[15] PRŮŠA, F., BERNATIKOVÁ, A., PALA, J. (2017) Ultra-High Strength Ti Grade 4 Prepared by Intensive Plastic Deformation In: Manufacturing Technology, Vol. 17, No. 5. pp. 819-822.

[16] KUČEROVÁ, L., JIRKOVÁ, H., MAŠEK, B. (2014). The Effect of Alloying on Mechanical Properties of Advanced High Strength Steels. In: Archives of Metallurgy and Materials, Vol. 59, No.3, pp. 1189-1192.

[17] CHIANG, J., BOYD, J.D., PILKEY, A.K. (2015). Effect of microstructure on retained austenite stability and tensile behaviour in an aluminium-alloyed TRIP steel, In: Material Science and Eng. A, Vol: 638, pp. 132-142. 